\title{
From the Cradle to the Grave. Demarcating Communities through Baptism and Burial in the Huddāye of Barhebraeus (d. 1286)
}

\section{Florian Jäckel}

\section{(2) OpenEdition}

Electronic version

URL: https://journals.openedition.org/hamsa/1283

DOI: $10.4000 /$ hamsa. 1283

ISSN: 2183-2633

Publisher

CIDEHUS - Centro Interdisciplinar de História Culturas e Sociedades da Universidade de Évora

Electronic reference

Florian Jäckel, "From the Cradle to the Grave. Demarcating Communities through Baptism and Burial in the Huddāyē of Barhebraeus (d. 1286) ", Hamsa [Online], 7 | 2021, Online since 07 September 2021, connection on 27 September 2021. URL: http://journals.openedition.org/hamsa/1283 ; DOI: https:// doi.org/10.4000/hamsa.1283

This text was automatically generated on 27 September 2021.

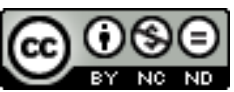

Hamsa est mise à disposition selon les termes de la Licence Creative Commons Attribution - Pas d'Utilisation Commerciale - Pas de Modification 4.0 International. 


\title{
From the Cradle to the Grave. Demarcating Communities through Baptism and Burial in the Hudd $\bar{a} y \bar{e}$ of Barhebraeus (d. 1286)
}

\author{
Florian Jäckel
}

1 Baptism designates the entrance into the Christian community while funeral rites symbolize the believer's passage to the afterlife. As rites of passage, these two rituals separate insiders from outsiders and are thus important markers for communal inclusion and exclusion. This paper analyzes stipulations regarding baptism and burial in the normative work called the Huddāye composed in Syriac by the Syriac Orthodox polymath and church leader Barhebraeus (d. 1286). First, I will examine what demarcation lines are drawn. Many of the rulings in the Huddāye explicitly address intrareligious demarcation lines. Another aspect, but a more implicit one, is how Christians grapple with their wider Islamic environment, e.g., when Barhebraeus provides an adaption of Islamic funeral practices for his Christian community. Thus, two types of outsiders can be identified: Christians of other denominations (e.g., East Syrians) and Muslims. Second, I will show how Barhebraeus compiles the Huddāye from earlier rulings and partially alters, expands and redacts them. I will demonstrate how he brings earlier normative texts, which contain the mentioned demarcation lines, into a coherent whole. Building upon recent research on Barhebraeus's normative works, this examination of the stipulations regarding baptism and burial frames the Huddāye not as a mere collection of traditional materials, but as a work engaging with his own time. The present paper thus provides an example of reading stipulations regarding rites of passage as the construction of community.

2 After briefly introducing the Huddāye and explaining my approach to this text, Barhebraeus's stipulations regarding both baptism and burial are assessed in respect to the respective outlook on other Christians as well as Muslims. Barhebraeus's Vorlagen for his Huddāye are identified and his textual strategies are analyzed ${ }^{1}$. 


\section{Barhebraeus's Huddāyē}

In the Huddāye, Barhebraeus does not merely compile texts from the normative tradition of his Syriac Orthodox Church. Rather, he shaped the Huddāye as a normative work, which "remains to this day the most comprehensive and systematic collection of canon law in the Syrian Orthodox Church"2. In this, he differs from earlier normative collections of his church, which simply compile various texts, such as the acts of late antique church councils or letters by individual church authorities ${ }^{3}$. The stipulations set down in the Huddāye should not simply be seen as a literary work of Barhebraeus as a versed scholar and compiler ${ }^{4}$. Rather, in his function as maphrian, the head of the Syriac Orthodox church in its eastern territories, he creates with the Ktāba $\bar{d}$-Huddāye ("Book of Guidings") a concise normative outlook for his community ${ }^{5}$, even if one cannot assume that all rulings in the Huddāye were used directly for judicial practice ${ }^{6}$. What is more, Barhebraeus used and adapted Islamic legal texts to create Christian rulings for normative problems, which often had not been dealt with earlier ${ }^{7}$. This is the case not only for rulings in worldly matters, such as family or mercantile law, but also for ritual aspects ${ }^{8}$.

Divided into 40 chapters, the Huddāye covers in its first seven chapters ritual or canon law proper, including one chapter on baptism (chap. 2) and one on burial and memorial services (chap. 6). The vast majority of stipulations in these two chapters are presented by Barhebraeus as referring back to earlier normative texts such as ancient church orders, the council of Nicaea (325 CE), or later texts from Syriac Orthodox Church authorities 9 . Notably, the references to earlier norms are not simply quotations but must be compared on an individual basis to their precedents to determine possible alterations introduced by Barhebraeus ${ }^{10}$. He also adds other stipulations with no precedent in the earlier Christian tradition, which are then simply entitled huddāya (ruling, guidance, admonition). Some of these, in turn, have an Islamic Vorlage, which is masked by their generic title ${ }^{11}$.

5 Given the creative use of legal texts in the Huddāye, I will approach it as a source for how Barhebraeus constructs community by marking who is inside and outside. He selects ritual stipulations regarding baptism and burial from numerous earlier sources. Although this simple fact shows that communal fluidity is an ongoing issue for the church hierarchy, the sources do not treat them as systematically as Barhebraeus does in the Huddāye. In fact, while in earlier normative works such rulings are often scattered, the Huddāyè's chapters on baptism and burial offer focused treatments of these topics. A majority of the material is treated in the present article. While I have selected the material here because it pertains to the questions at hand, it does not only represent a small fraction of Barhebraeus's treatment of the two topics, but rather a substantive and representative part of it. Reading his stipulations as a whole, I argue, can help in understanding how Barhebraeus envisages his community to interact with other Christian groups as well as with the now dominant Muslim community. Baptism and burial are fundamental aspects of communal life, where this interaction becomes apparent either through the inclusion and exclusion of individuals or through distinct rituals ${ }^{12}$.

6 My approach thus seeks to answer two sets of questions: (1) what practices and places with a distinctly Christian character does Barhebraeus prescribe? How are these set 
apart - explicitly or implicitly - from other practices and places? (2) How does Barhebraeus in the Huddāye draw lines between followers of his own church and others in respect to baptism and burial? Are there differences in respect to laypeople and clergy? How are group denominations used? Some of these questions can be answered by comparing the individual stipulation with its Vorlage. Others will need to be explained out of the textual context in which Barhebraeus places them. Rather detailed observations on the text, its respective sources and the differences between them are found in the footnotes.

\section{From the cradle (baptism)...}

7 Research on the history of baptism has mostly focused on the theological views and debates of church authorities. Less frequently analyzed is the social aspect of an individual's inclusion into the group through the ritual ${ }^{13}$. The baptism ritual can be seen as a foundational act that constitutes a social group, in that it generally marks and performatively creates affiliation and non-affiliation ${ }^{14}$. As Louth points out, a tension developed over the centuries between the original notion of the church as a "voluntary society" and the "natural community" it started to become from the fourth century onward ${ }^{15}$. The ritual and theological character of baptism as a kind of conversion remained, although infant baptism became the predominant practice, strongly linking birth and entrance into the (natural) community ${ }^{16}$.

When thinking about the social aspect of baptism in the medieval Middle East, however, the situation becomes more complicated again. Not only is there more than one church but many other religious groups as well. All these groups can be considered to be "natural communities". Thus, infant baptism seems to be a matter of course for Barhebraeus ${ }^{17}$. However, there are aspects of fluidity (e.g., through intermarriage) and voluntary association (through conversion) as well. Barhebraeus's rulings on baptism as marking inclusion and exclusion must be seen against this background.

9 The chapter on baptism in Barhebraeus's Huddāye is divided into five sections. In the first section, he deals with valid and invalid baptism. In the second section, norms for emergency baptism are prescribed. The third section contains rulings regarding the myron oil or chrism as well as the water used in baptism. The time of baptism is stipulated in the fourth section, while the ritual completion of baptism is prescribed in the fifth section. The rulings analyzed here mostly belong to the first, second and fourth sections. In the following, I first highlight how Barhebraeus establishes the Christian character of baptism through his rulings. Next, it is shown how he renders and deals with different groups of outsiders. Lastly, I treat Barhebraeus's regulation of boundaries.

\section{The Christian character of baptism and its embeddedness in the church's authority}

What is necessary for a proper baptism? Barhebraeus refers back to the apostles, which implies that his Vorlage comprises some of the numerous normative texts attributed to the apostles in the eastern churches ${ }^{18}$. The first and central aspect is the baptism according to the triune formula, which is also symbolized by the threefold submersion of the baptismal candidate into the water ${ }^{19}$. The ritual agent is either a bishop or a 
priest $^{20}$. Compared to their precedents, the rulings are slightly abridged, but also further specified by Barhebraeus ${ }^{21}$. However, by placing these rulings at the beginning, Barhebraeus stresses the distinctly Christian character and the embeddedness of the ritual in the authority of the clergy from the outset.

11 In the second section, on emergency baptism, Barhebraeus puts together several rulings from the earlier tradition, which highlight what one could call "the social reality of compromise". In other words, communal integrity (marked by baptism) is more important than strictly following the rules ${ }^{22}$. In the Huddāye, Barhebraeus refers to "Timothy the patriarch" (of Alexandria, d. ca. $384 \mathrm{CE}$ ) to declare that a person usually needs to be ritually pure; for example, people who are possessed by a demon or menstruating women do not fall in this category. However, if death is near, this rule does not apply ${ }^{23}$. Concerning purity and gender, separation according to gender is apparently an important aspect of Christian values as well ${ }^{24}$. Furthermore, a child close to death can be baptized with water, which is "not from a river, pond or any other water body"25. Compared to the Vorlage, Barhebraeus even makes an addition: if the priest does not baptize the child at once, but tries first to "bind the angel", he is dismissed ${ }^{26}$. I suggest that the whole problem must be seen not only as a matter of salvation for the child, but as pastoral care for the parents and family as well ${ }^{27}$.

In a later huddāyā in the second section, Barhebraeus refers to stipulations by Severus of Antioch (d. $538 \mathrm{CE}$ ) to declare baptism by laypeople invalid ${ }^{28}$. By excluding laypeople from this function, even in emergencies, and decreeing that even deacons cannot complete the baptism (i.e., they cannot apply the myron oil) ${ }^{29}$, Barhebraeus further reinforces the grip of the church hierarchy over the community. In case ecclesial personnel is not loyal, additional measures are taken, as set out in another stipulation: if a bishop or a priest accepts the baptism carried out by a heretical ${ }^{30}$ community, he loses his office ${ }^{31}$. Barhebraeus thus fosters the exclusion of outsiders by appointing the loyal church hierarchy as gatekeepers. In sum, the Christian character of the ritual of inclusion is underlined from the beginning. At the same time, communal integrity in case of emergency ranks higher than ritual rigor.

\section{Two groups of outsiders set against insiders}

According to baptism as inclusion, the validity of baptism at the hands of different heretical groups is the main issue in the rulings of the first section on "proper baptism". Barhebraeus quotes a wide variety of earlier normative authorities ${ }^{32}$. Even though there were diverse creeds and religious communities in Barhebraeus's times, it is hard to imagine that certain groups mentioned in the Huddāye, such as the Novatians, Photinians or Phrygians in the canons of Laodicea (ca. $350 \mathrm{CE}$ ), competed with Barhebraeus's own church ${ }^{33}$. But why then take up rulings pertaining to groups that no longer posed a threat? Concerning Barhebraeus's ruling of apostasy, Weltecke has argued convincingly that the reference to conversion to Arianism subtly refers to conversion to Islam $^{34}$. I suggest reading Barhebraeus's many stipulations concerning the acceptance or rejection of the baptism by outsiders in a similar way. Certain groups whose baptism is not accepted, i.e., who are clearly outsiders, must apparently be understood as non-Christian. Among them are Arians ${ }^{35}$, which likely refers to Muslims. Others, who had been "baptized by the heretics in the name of the Trinity", are only consecrated with myron oil, if they denounce their heresy ${ }^{36}$. These kinds of heretics 
include Nestorians or Julianists (who are likened to Chalcedonians) ${ }^{37}$ and are apparently seen as proper Christians, who do not need to be re-baptized. By including Chalcedonians and Nestorians, Barhebraeus covers the two relevant Christian groups for his own time. The central point of his stipulations in the Huddāye, I argue, is the communal integrity expressed through proper baptism as inclusion into the group. A distinction is made between two kinds of outsiders: (1) non-Christians and problematic heretics and (2) somehow more acceptable heretics. For the second group, other rituals, namely anointment, penance or prayer are decreed. The outsiders are thus clearly set against the insiders and distinct rituals are used to mark the different boundaries ${ }^{38}$.

At first sight, how exactly Barhebraeus distinguishes between these two different groups of outsiders seems hard to grasp. One reason is the numerous groups Barhebraeus lists; another reason is that some stipulations seem stricter than others do, especially when Barhebraeus cites Cyprian of Carthage (d. $258 \mathrm{CE}$ ). The latter had set the unity of the church against the unity or singularity of baptism: baptism by heretics must not be accepted. In fact, there can be no such thing as re-baptism, only one baptism in the one Catholic Church ${ }^{39}$. However, Barhebraeus qualifies this stance by referring to Severus, who juxtaposes Cyprian's dictum with a less strict position taken by other church authorities such as the Council of Nicaea $(325 \mathrm{CE})^{40}$. The reader is thus presented with different opinions, while, and at the same time, certain rulings are abrogated ${ }^{41}$. In sum, Barhebraeus seemingly uses pagans and problematic heretics mentioned in pre-Islamic texts as a code for Muslims (and Jews?), while those heretics whose baptism is accepted represent other Christians.

\section{Regulating boundaries}

In some of the rulings on baptism, fluid or unstable communal belonging is at stake. For example, Barhebraeus stipulates how believers who converted to Islam are to be treated when they want to return to the community. The renegades are not to be baptized again, but the bishop has to say a "prayer of penance" over them and then they can be readmitted ${ }^{42}$. Here, Barhebraeus can turn to a Syriac-Christian ruling from Islamic times, namely one by Jacob of Edessa $(\mathrm{d} .708 \mathrm{CE})^{43}$. The ruling shows that, even in Barhebraeus's time, conversion to Islam was seemingly not irreversible. It also raises the question if apostasy from Islam was not persecuted at all times or in all areas.

Another decree in the Huddāye implies cases in which orthodox people have their children baptized by heretics or, vice versa, heretics want their children to be baptized by the orthodox community. A possible explanation can either be a marriage of partners from different communities or the resettlement to areas where clerics of one's own community are not to be found. The orthodox who "went astray" can be readmitted together with their children, if they swear not to return to the heretics, while heretics who have their children baptized by the orthodox must swear not to take them back out of the community ${ }^{44}$. Similar cases of communal interaction and how they are treated are found throughout the Syriac tradition ${ }^{45}$.

17 There is yet another ruling, which reinforces the boundaries and the role of the clergy as gatekeepers. Similar to the dismissal of bishops or priests accepting baptism by outsiders, Barhebraeus refers to George, Bishop of the Arabs (d. 724 CE), when stating that a priest who admits a pagan (hanpa) or a heretic to the Eucharistic mysteries or to baptism should be dismissed ${ }^{46}$. Notably, Barhebraeus adds a huddāya of his own that the 
same holds true for priests admitting people "who do not testify to believe". Likely, this addresses the acceptance of outsiders without any proof of their loyalty ${ }^{47}$. Similar to Jacob of Edessa, George's rulings stem from the time after the Arabic conquests. Muslims fall into this category, even if the text only refers to them as pagans. With his ruling, Barhebraeus ensures that outsiders are not casually admitted into the church.

To this point, I have shown how, in the Huddāye, Barhebraeus's systematic selection of rulings from the earlier normative tradition shapes baptism as an important boundary between outsiders and insiders. The stipulated character of the ritual as distinctly Christian corresponds to the creed and values of the community. The church hierarchs are made gatekeepers and sanctioned if they are not loyal, i.e., when transgressing the rules. Still, compromises to these rules in liminal situations underline the character of baptism as a marker of social inclusion into a "natural community" over against the theological and ritual rigor of a purely "voluntary society". In the next part of the article, similar observations can be made regarding the rulings Barhebraeus decrees for the burial practice.

\section{... to the grave (burial)}

19 Christian funeral rites and burial can be conceived in two ways. On the one hand, they correspond to baptism as a rite of passage, here marking the end (rather than entrance) of a person's membership in the community. Different from baptism, with its tension between entry into natural community and voluntary society as pointed out above, Christian funeral rites are more easily compared with funeral rites in other traditions.

On the other hand, belief in an afterlife is a strong aspect of the Christian religion. In this respect, a believer remains part of the community and proper funeral rites mark the communal inclusion of a deceased member (or the exclusion of an outsider) beyond bodily death. This is visible also in the separation of burial grounds or in participation in funeral processions ${ }^{48}$.

21 In addition, the social aspect of the burial must be considered: death disrupts a community and funeral rites help the community cope with this disruption. However, other social ties, e.g., one's neighborhood or intermarriage, might intersect with communal belonging based on religion. Accordingly, social compromise or religious rigor are also at stake, just as with baptism.

Chapter six in Barhebraeus's Huddāye includes two sections: the first treats funeral services, burial and graves, while the second treats the remembrance of the dead, unlawful lamentations and how heterodox are to be commemorated. In the following, I first discuss the Christian character of the prescribed practices. Second, the issue of intercommunal boundaries as well as inclusion and exclusion through funeral rites are analyzed.

\section{Christian burial according to the Huddāyē}

23 Regarding the Christian character of the funeral rites, it is important to note how Barhebraeus stipulates the preparation of the deceased person for burial. That this somewhat lengthy paragraph is entitled a huddāy $\bar{a}$ strongly suggests that he cannot easily draw on the earlier tradition and reverts to an Islamic source, which he does not 
want to refer to by name. To this point, I have not been able to identify earlier Syriac Orthodox sources, or Christian ones more broadly, which would stipulate how a dead person is prepared for burial in the same detailed way one finds in the Huddāye $\bar{e}^{49}$. This said, I here translate the entire passage:

"When the hour comes, the face of the one dying is turned east. They are girded with the zonnāra [i.e., a belt specific to Christians], their hands are folded on their chest and they are reminded to say, "I believe in God, Father, Son and Holy Spirit." And when they have died, their eyes are shut.

If [the deceased] is a bishop, a priest, a deacon or a monk, he is brought to the church (lit. temple, hayklā) with hymns and lights. Three services of Psalms are completed on his behalf. Afterwards, readings from the Old and New [Testament] and the Gospels are recited. Then, he is brought up to the altar and processed around it three times, while it is said: "Rest in peace, o holy altar, rest in peace, o church and all clergy. The church, in which I have served: may peace reign in it." Then, the priest says the prayer over the ointment (mešh̆a $)$ and applies it to [or: pours it over] their chest in the figure of the cross three times, while saying: "[May you be granted] rest from labor, deliverance from troubles and the delight of the saints - in the name of the Father, Son and Holy Spirit."

Then he is wrapped in linen, while his undergarment is not to be removed. And he is clothed in the pina [i.e., a liturgical vestment] and he is put in the grave with his face towards the east.

If [the deceased] is a layperson, the services are carried out in their house. And they are brought to the cemetery and shrouded. Earth instead of ointment is applied on the linen, on their face, their chest and their feet." ${ }^{50}$

In fact, what Barhebraeus prescribes here is a combination of what one finds regarding Islamic funeral practice in al-Qudūrī's (d. 1036/7 CE) normative work and some aspects from the earlier Christian tradition ${ }^{51}$. The parallels to al-Qudūrì's Muhtașar are rather slight compared with Barhebraeus's adaptions in other instances. What are the main differences? Naturally, Barhebraeus changes the creed which the dying person is encouraged to pronounce: it is belief in the Trinity rather than the two Šahädas (unity of God and prophethood of Muhammad) ${ }^{52}$. The Islamic qiblah, i.e., the direction to Mecca, is faced when the person is prepared for death as well as in the grave. Barhebraeus replaces it by the usual Christian direction of prayer towards the East. The bathing of the person is omitted by Barhebraeus here, but is treated earlier in the section; I will come back to this later. However, Barhebraeus stipulates girding the deceased with the zonnārā as a typical Christian feature ${ }^{53}$. The anointment of the dead person is already found in the work On the Ecclesiastical Hierarchy of Pseudo-Dionysius the Areopagite (fl. ca. $500 \mathrm{CE})^{54}$, but Barhebraeus seems to add that this must be done in the form of the cross. Al-Qudūrī in turn stipulates the application of balm (Ar. hanūțt) to the bodily parts used in the Islamic practice of prostration in prayer.

Barhebraeus uses an Islamic "skeleton" for regulating the preparation of the dead, which had not been stipulated before, but fleshes it out with a distinctly Christian character. The Christian adaptations can be read as yet another attempt of Barhebraeus to foster communal integrity, in that these funeral rites clearly mark differences in ritual compared to the surrounding Islamic culture. What is more, the important Christian distinction between clergy and lay people is once again found in the Huddāyè s prescriptions, regarding the place for the funeral prayer (church vs. private home), the substance used in anointing (ointment vs. earth) and, apparently, in regard to the liturgical rigor ${ }^{55}$. 

which is again entitled a huddāy $\bar{a}$ and thus forms a likely candidate for Barhebraeus's appropriation of Islamic norms. As I have shown in detail elsewhere ${ }^{56}$, there are several noteworthy points in regard to this rite. First, Barhebraeus seemingly adopts alGhazālī's Islamic notion of a child's human shape as an indication of its animation by giving it a Christian Aristotelian reading. Other Islamic aspects of the funeral prayer for the child are dismissed, as they stand in tension with Christian anthropology. Second, the idea of proper funeral rites for an unbaptized child is seemingly strange to Barhebraeus's audience. He positions his ruling against unnamed authorities who apparently rule out this practice. Barhebraeus argues that the parents' baptism counts for the child; in other words, the inclusion of the parents in the community extends to their child ${ }^{57}$. This ruling on the burial of the miscarried child can be read along two lines. To begin with, the pastoral implications of this care for bereaved parents and family strengthen communal integrity. What is more, the adaption of this Islamic practice presents Barhebraeus's Christian community as similar yet distinct from the now dominant faith, which had allowed parents to bury their prematurely deceased children.

As stated earlier, Barhebraeus does not mention the washing of the body as part of preparing the deceased person for burial, which is, however, central to the Islamic practice he seemingly adapts in other points. Yet, earlier in the first section, he does treat the washing. Barhebraeus here summarizes a longer set of norms by Jacob of Edessa $^{58}$. According to the latter, the washing of the dead is not canonical ( $q \bar{a} \bar{n} n$ nonaytā) nor has Dionysius (Pseudo-Dionysius the Areopagite) decreed this. The custom (' $y \bar{a} d \bar{a})$ is assumed to go back to those who were sick with ulcers and were washed and anointed with balm $(\text { besm } \bar{a})^{59}$. Barhebraeus makes additional stipulations on the washing of the dead in reference to the Persians (Pārsāyē). When bishops, priests, or monks die, only their face, hands and feet are washed; laypeople are washed completely ${ }^{60}$. However, men wash men and women wash women. These rulings uphold the Christian division of clergy and laypeople as well as Christian separation according to gender when it comes to bodily aspects of the ritual ${ }^{61}$.

One more demarcation Barhebraeus draws is the wrongful custom of lamentations ${ }^{62}$. It had been seen as an issue by earlier church authorities and seems to have been still prevalent in his time. (This practice was contested by Muslims as well.) Since the wrongdoers are mostly alleged to be women, ruling out lamentations can be seen as another regulation of gender norms $\mathrm{s}^{63}$. Hence, similar to what was observed in the case of baptism, the Christian character of the funeral ritual and the specific social and ritual distinctions concerning gender and rank in the church hierarchy become tangible in the Huddāye.

\section{Again: regulating boundaries}

29 In many of the rulings on funeral rites in the Huddāye, Barhebraeus treats the issue of unclear boundaries between insiders and outsiders. In section one, Barhebraeus summarizes three decrees by John of Tella (d. $538 \mathrm{CE})^{64}$. Believers should not be sanctioned themselves, just because their dead are commemorated by heretics. In the Vorlage, the funeral service by the heretics is portrayed as something done against the will of the deceased. In general, one would think of children, wives, or other individuals 
in weak positions overruled by other members of the family or community. This does not come out clearly in Barhebraeus's summary. Another ruling by John states that, if there is a burial ground of a believer, another believer should not be buried alongside a heretic. Here, the spatial separation beyond death becomes apparent.

Furthermore, according to John, a believer who has died among heretics can be prayed for by heretical priests. Barhebraeus cites John's explanation for having heretical priests pray for the orthodox: it would not be right to bury someone without a funeral service. Again, the reason for these problems might be either intermarriage or family relations as well as settlement structure. Noteworthy is the following huddāyā: in this specific case, rather than a heretical priest, orthodox laypeople are entitled to bury their dead if no orthodox priest is available ${ }^{65}$. Once more, social integrity and the marking of boundaries thus becomes more significant than ritual rigor. The orthodox laypeople are assigned the role of gatekeepers if no loyal clergy is at hand.

In the second section of the Huddāyes chapter on burial, the commemoration of heterodox (hrānay šubhāa) is explicitly part of the section heading. Again, one encounters two types of outsiders: heretics (i.e., other Christians) and pagans. Referring to Jacob of Edessa, Barhebraeus treats the case of believing children who want to commemorate their heretical parents ${ }^{66}$. According to Jacob, if the parents were leaders $(q \bar{a} y o m \bar{e})$ of the heresy, it is not lawful. However, if they were from among the common people (men 'ammā pšița), it is granted. Here, only the heretics and no pagans appear, but another striking boundary is drawn, i.e., between leaders and commoners. From the terms qāyome and 'ammā pšițā it does not seem that a ritual distinction between clergy and laypeople is meant, but a social one directed against individuals in higher ranks, which represent the outsider community ${ }^{67}$. Seemingly inserted ${ }^{68}$ in the discourse by Jacob are the opinions of Dionysius and Iyoānnis (Chrysostomos?), which Barhebraeus refers to: heretics are allowed to be commemorated, but not pagans (hanp $\bar{e})^{69}$. For the time being, it is not clear if this insertion can be seen as another abrogative measure towards an earlier ruling by Barhebraeus.

One last aspect treated here are funeral processions. As part of the funeral rite, their importance stretches beyond the immediate surrounding of the deceased and are public displays of communal belonging. Naturally, it is not only religious or confessional affiliation that plays a role. Strikingly, what Barhebraeus stipulates following Jacob of Edessa is rather liberal and willing to compromise: out of human love (metțol hubbā nāšāya $\bar{a}$ ), cross-communal participation in funeral processions is allowed ${ }^{70}$.

\section{Conclusion}

Baptism and funeral rites are important rites of passage that mark a person's inclusion into or exclusion from the Christian community. By analyzing Barhebraeus's Huddāye as a redaction, alteration and adaption of the earlier normative tradition, I have shown how his readers were provided with a coherent outlook on communal integrity vis-àvis other Christian groups as well as Muslims, each group representing a different kind of outsiders. Distinct rituals and/or stipulations are often provided for each group and rulings are issued to mediate the transgression of boundaries. The Christian character of the rites is also highlighted by Barhebraeus throughout the stipulations. This includes a distinction between laypeople and clergy, the latter employed as loyal gatekeepers guarding the intended integrity. On the other hand, the importance of 
social compromise has to be noted: life's necessities beat theological rigor, as it were. All in all, the findings underline the importance of research on the social implications that underlie the surface of works treating canon law or theology.

\section{BIBLIOGRAPHY}

\section{Bibliography and Printed Sources}

ABRAHAMSE, Dorothy, "Rituals of Death in the Middle Byzantine Period", The Greek Orthodox Theological Review 29 (1984), pp. 125-134.

AL-ĠAZĀLİ, Kitāb al-Wasīt, ed. Aḥmad Maḥmūd Ibrāhīm, al-Wasịt fì l-maḍab. 6 volumes, Cairo, Dār as-Salām, 1997.

AL-QUDŪRĪ, al-Muhtașar, ed. and trans. Țāhir Maḥmood Kiānī, The Mukhtașar al-Qudūrī of Imām [...] al-Qudūri al-Baghdādi (362 AH-428 AH). A manual of Islamic Law According to the Hanafi School, London, Ta-Ha, 2015.

BASILIUS, Archbishop, "Burial Rites and Practices" in Coptic Encyclopedia, ed. Aziz Suryal Atiya, vol. 2, pp. 425-426 (https://ccdl.claremont.edu/digital/collection/cce/id/389/rec/30, accessed 2021-04-23).

BEDJAN, Paulus, Nomocanon Gregorii Barhebraei, Leipzig, Harrassowitz, 1898.

BODDENS HOSANG, F.J.E., Establishing Boundaries. Christian-Jewish Relations in Early Council Texts and the Writings of Church Fathers, Leiden and Boston, Brill, 2010.

BOSANQUET, Antonia, Minding their Place. Space and Religious Hierarchy in Ibn al-Qayyim's Aḥkām ahl al-dhimma, Leiden and Boston, Brill, 2020.

BOURDIEU, Pierre, Language and Symbolic Power, Cambridge and Oxford, Polity Press, 1991.

BRANDES, Wolfram, “Taufe und soziale/politische Inklusion und Exklusion in Byzanz", Rechtsgeschichte - Legal History 21 (2013), pp. 75-88.

BROCK, Sebastian P., "Severus of Antioch", in Gorgias Encyclopedic Dictionary of the Syriac Heritage. Electronic Edition, ed. idem et al. (https://gedsh.bethmardutho.org/Severus-of-Antioch, accessed 2021-04-23).

BROCK, Sebastian P. and David G.K. Taylor, The Hidden Pearl. The Syrian Orthodox Church and its Ancient Aramaic Heritage, Rome, Trans World Film Italia, 2001.

CHABOT, Jean-Baptiste, Synodicon Orientale ou Recueil des synodes nestoriens, Paris, Klincksieck, 1902.

COHEN, Mark, Under Crescent and Cross. The Jews in the Middle Ages, Princeton and Oxford, Princeton University Press, 2008. 
COHEN, Mark, "Defending Jewish Judicial Autonomy in the Islamic Middle Ages", in Law and Religious Minorities in Medieval Societies. Between Theory and Praxis, ed. Ana Echevarria et al. Turnhout, Brepols, 2016, pp. 13-33.

CONLIN, Patrick, "Eradicating the Root of Hatred. A Survey of Bar Hebraeus's Ecumenism", in UWM Religious Studies Student Organization 2019 Conference: Religion and the Human Condition, 2018 (Available online: https://www.academia.edu/37843603/ Eradicating_the_Root_of_Hatred_The_Development_of_Bar_Hebraeuss_Ecumenism DE VRIES, Wilhelm, Sakramententheologie bei den syrischen Monophysiten. Rome: Pontificium Institutum Orientalium Studiorum, 1940.

DÖLGER, Franz Joseph, “Totenritual der Jakobiten nach Ricaldo da Monte Croce”, Antike und Christentum 5.2 (1936), pp. 149-150.

EDELBY, Néophyte, "The Legislative Autonomy of Christians in the Islamic World", in Muslims and Others in Early Islamic Society, ed. Robert Hoyland, Aldershot and Burlington, VT, Ashgate, 2004, pp. 37-82.

EL CHEIKH, Nadia Maria, Women, Islam, and Abbasid Identity. Cambridge, MA and London, Harvard University Press, 2015

EMON, Anver M., Religious Pluralism and Islamic Law. Dhimmīs and Others in the Empire of Law, Oxford, Oxford University Press, 2012.

FATTAL, Antoine, Le statut légal des non-musulmans en pays d'Islam, Beirut, Imprimerie Catholique, 1958, pp. 344-365.

TER HAAR ROMENY, Bas (ed.), Jacob of Edessa and the Syriac Culture of His Day, Leiden and Boston, Brill, 2008.

HALEVI, Leor, "Funerary practices", in Encyclopaedia of Islam, THREE, ed. Kate Fleet et al. (http:// dx.doi.org/10.1163/1573-3912_ei3_COM_27205).

HALEVI, Leor, Muhammad's Grave. Death Rites and the Making of Islamic Society, New York, Columbia University Press, 2007.

HOENERBACH, Wilhelm \& Otto Spies, Fiqh an-Nașrāniya. Das Recht der Christenheit (Corpus Scriptorum Christianorum Orientalium 162, 168), Louvain, Imprimerie Orientaliste L. Durbecq, 1956-1957.

HOYLAND, Robert G., Seeing Islam as Others Saw it. A Survey and Evaluation of Christian, Jewish and Zoroastrian Writings on Early Islam, Princeton, The Darwin Press, 1997.

JÄCKEL, Florian, "Re-Negotiating Interconfessional Boundaries through Intertextuality. The Unborn in the Kțābāa $\underline{d}$-Huddāye of Barhebraeus (d. 1286)", Medieval Encounters 26.2 (2020), pp. 95127.

JENNER, Konrad D., "The Canons of Jacob of Edessa in the Perspective of the Christian Identity of His Day" in Jacob of Edessa and the Syriac Culture of His Day, ed. Bas ter Haar Romeny, Leiden and Boston, Brill, 2008, pp. 101-111.

KAUFHOLD, Hubert, Syrische Handschriften juristischen Inhalts in südindischen Bibliotheken, Vienna, Verlag der Österreichischen Akademie der Wissenschaften, 1989.

KAUFHOLD, Hubert, "Sources of Canon Law in the Eastern Churches", in The History of Byzantine and Eastern Canon Law to 1500, ed. Wilfried Hartmann and Kenneth Pennington, Washington, D.C., The Catholic University of America Press, 2012, pp. 215-342. 
KAYSER, Carl, Die Canones Jacob's von Edessa, Leipzig, J.C. Hinrichs'sche Buchhandlung, 1886.

KIRAZ, George A., "Syrian Orthodox and Syrian Catholics", in The Rowman \& Littlefield Handbook of Christianity in the Middle East, ed. Mitri Raheb and Mark A. Lamport, Lanham, MD and London, Rowman \& Littlefield, 2020, pp. 244-253.

KOHLHAAS, Radbert, Jakobitische Sakramententheologie im 13. Jahrhundert. Der Liturgiekommentar des Gregorius Barhebraeus, Münster, Westfalen, Aschendorff, 1959.

DE LAGARDE, Paul, Reliquiae Iuris Ecclesiastici Antiquissimae, Syriace, Leipzig, B.G. Teubner, 1856.

LOUTH, Andrew, “'Fiunt, non nascuntur Christiani.' Conversion, Community, and Christian Identity in Late Antiquity”, in Being Christian in Late Antiquity. A Festschrift for Gillian Clark, ed. Carol Harrison et al., Oxford, Oxford University Press, 2014, pp. 109-119.

MENZE, Volker L., "Yuhanon of Tella", in Gorgias Encyclopedic Dictionary of the Syriac Heritage. Electronic Edition, ed. Sebastian P. Brock et al. (https://gedsh.bethmardutho.org/Yuhanon-ofTella).

MEYER, Christoph H. F., "Taufe und Recht. Einige einführende Bemerkungen”, Rechtsgeschichte Legal History 21 (2013), pp. 68-73.

MOGEN, Sharon L. M., Mourning the Dead in Christian Late Antiquity. Dissertation, University of Calgary, 2020.

MOUAWAD, Ray Jabre, “Recherche sur quelques pratiques funéraires des maronites", Parole de l'Orient 23 (1998), pp. 89-110.

MURRE-VAN DEN BERG, Heleen, "Syriac Christianity”, in The Blackwell Companion to Eastern Christianity, ed. Ken Parry, Malden, MA, Wiley-Blackwell, 2007, pp. 249-268.

NALLINO, Carlo A., "Il diritto musulmano nel Nomocanone siriaco cristiano di Barhebreo", Rivista degli studi orientali 9 (1921-1923), pp. 512-68.

NAU, François, “Les canons et les préceptes des Jean, évêque de Tella”, in Les canons et les résolutions canoniques de Rabboula, Jean de Tella, Cyriaque d'Amid, Jacque d'Édesse, Georges des Arabes, Cyriaque d'Antioch, Jean III, Théodose d'Antioche et des Perses, ed. idem, Paris, P. Lethielleux, 1906, pp. $1-30$.

NAU, François, "Les résolutions canonique de Jacques d'Edesse", in Les canons et les résolutions canoniques de Rabboula, Jean de Tella, Cyriaque d'Amid, Jacque d'Édesse, Georges des Arabes, Cyriaque d'Antioch, Jean III, Théodose d'Antioche et des Perses, ed. idem, Paris, P. Lethielleux, 1906, pp. 30-76.

NAU, François, "Littérature canonique syriaque inédite", Revue de l'Orient chrétien - Deuxieme Série, 4 (1909), pp. 1-49 and pp. 113-130.

OHME, Heinz, "Sources of the Greek Canon Law to the Quinisext Council (691/2). Councils and Church Fathers", in The History of Byzantine and Eastern Canon Law to 1500, ed. Wilfried Hartmann and Kenneth Pennington, Washington, D.C., The Catholic University of America Press, 2012, pp. 24-114.

PARKER, John, The Works of Dionysius the Areopagite. Translated into English from the Original Greek, London and Oxford, James Parker and Co., 1897.

PENN, Michael P., Envisioning Islam. Syriac Christians and the Early Muslim World, Philadelphia, University of Pennsylvania Press, 2015.

PINGGÉRA, Karl, “Myron”, in Kleines Lexikon des christlichen Orients, ed. Hubert Kaufhold, Wiesbaden, Harrassowitz, 2007, pp. 361-363. 
POPKES, Enno Edzard, "Die Tauftheologie Cyprians und die Geschichte des altkirchlichen 'Ketzertaufstreits”, in Ablution, Initiation, and Baptism. Late Antiquity, Early Judaism, and Early Christianity, ed. David Hellholm et al., Berlin, De Gruyter, 2011, pp. 1051-1170.

REBILLARD, Éric, The Care of the Dead in Late Antiquity, Ithaca and London, Cornell University Press, 2012, pp. 13-36.

RUSTOW, Marina, “At the Limits of Communal Autonomy. Jewish Bids for Intervention from the Mamluk State”, Mamlūk Studies Review 13.2 (2009), pp. 133-159.

RYSSEL, Viktor, Georgs des Araberbischofs Gedichte und Briefe, Leipzig, S. Hirzel, 1891.

SALVESEN, Alison G., "Ya'qub of Edessa", in Gorgias Encyclopedic Dictionary of the Syriac Heritage. Electronic Edition, ed. Sebastian P. Brock et al. (https://gedsh.bethmardutho.org/Yaqub-of-Edessa, accessed 2021-04-23).

SCHMITT, Jens Ole, “Some Remarks on East Syrian Influences Found in Barhebraeus's Works", in Griechische Philosophie und Wissenschaft bei den Ostsyrern. Zum Gedenken an Mār Addai Scher (18671915), ed. Matthias Perkams and Alexander Schilling, Berlin, De Gruyter, 2020, pp. 157-176.

SCHMITT, Jens Ole, Barhebraeus, Butyrum Sapientiae, Physics. Introduction, Edition, Translation, and Commentary, Leiden, Brill, forthcoming.

Scriptorum veterum nova collectio, volume 10, ed. Angelo Mai, Rome, Typis Vaticanis, 1838.

SELB, Walter, Die Geschichte des Kirchenrechts der Westsyrer, Wien, Verlag der Österreichischen Akademie der Wissenschaften, 1989.

STRECKER, Christian, "Taufrituale im frühen Christentum und in der Alten Kirche. Historische und ritualwissenschaftliche Perspektiven", in Ablution, Initiation, and Baptism. Late Antiquity, Early Judaism, and Early Christianity, ed. David Hellholm et al., Berlin, De Gruyter, 2011, pp. 1383-1440.

TAKAHASHI, Hidemi, Barhebraeus. A Bio-Bibliography, Piscataway, NJ, Gorgias Press, 2013.

TAKAHASHI, Hidemi, "Reception of Islamic Theology among Syriac Christians in the Thirteenth Century. The Use of Fakhr al-Dīn al-Rāzī in Barhebraeus's Candelabrum of the Sanctuary", Intellectual History of the Islamicate World 2 (2014), pp. 170-192.

TAKAHASHI, Hidemi, “The Influence of al-Ghazālī on the Juridical, Theological and Philosophical Works of Barhebraeus", in Islam and Rationality. The Impact of al-Ghazali. Papers Collected on his 900th Anniversary, ed. Georges Tamer and Frank Griffel, Leiden and Boston, Brill, 2015, pp. 303-325,

TANNOUS, Jack, "Between Christology and Kalām? The Life and Letters of George, Bishop of the Arab Tribes", in Malphono w-Rabo d-Malphone. Studies in Honor of Sebastian P. Brock, ed. George Kiraz, Piscataway, NJ, Gorgias Press, 2009, pp. 671-716.

TANNOUS, Jack, The Making of the Medieval Middle East. Religion, Society, and Simple Believers, Princeton and Oxford, Princeton University Press, 2018.

TEULE, Herman G.B., "Juridical Texts in the Ethicon of Barhebraeus", Oriens Christianus 79 (1995), pp. 23-24.

TEULE, Herman G.B., "Jacob of Edessa and Canon Law", in Jacob of Edessa and the Syriac Culture of His Day, ed. Bas ter Haar Romeny, Leiden and Boston, Brill, 2008, pp. 83-100.

VAN GINKEL, Jan J. et al. (eds.), Redefining Christian Identity. Cultural Interaction in the Middle East since the Rise of Islam, Leuven, Paris and Dudley, MA, Peeters and Departement Oosterse Studies, 2005. 
VAN ROMPAY, Lucas, "Severus, Patriarch of Antioch (512-538), in the Greek, Syriac, and Coptic Traditions", Journal of the Canadian Society for Syriac Studies 8 (2008), pp. 3-22.

VAN ROMPAY, Lucas, "Synodicon Orientale", in Gorgias Encyclopedic Dictionary of the Syriac Heritage. Electronic Edition, ed. Sebastian P. Brock et al. (https://gedsh.bethmardutho.org/ Synodicon-Orientale).

VÖÖBUS, Arthur, The Synodicon in the West Syrian tradition (Corpus Scriptorum Christianorum Orientalium 368, 376), Louvain, Sécrétariat du CorpusSCO, 1975-1976, 2 volumes.

VÖÖBUS, Arthur, Syrische Kanonessammlungen. Ein Beitrag zur Quellenkunde (Corpus Scriptorum Christianorum Orientalium 307, 317), Louvain, Secrétariat du CorpusSCO, 1970.

WEITZ, Lev, "Al-Ghazālī, Bar Hebraeus, and the 'Good Wife"', Journal of the American Oriental Society 134.2 (2014), pp. 203-223.

WEITZ, Lev, Syriac Christians in the Medieval Islamic World. Law, Family, and Society. Dissertation, Princeton University, 2013.

WEITZ, Lev, Between Christ and Caliph. Law, Marriage, and Christian Community in Early Islam, Philadelphia, University of Pennsylvania Press, 2018.

WELTECKE, Dorothea, "60 Years after Peter Kawerau. Remarks on the Social and Cultural History of Syriac-Orthodox Christians”, Le Muséon 121.3-4 (2008), pp. 311-335.

WELTECKE, Dorothea, “Zum syrisch-orthodoxen Leben in der mittelalterlichen Stadt und zu den Hūddōyē (dem Nomokanon) des Bar 'Ebrōyō”, in Orientalia Christiana. Festschrift für Hubert Kaufhold zum 70. Geburtstag, ed. Peter Bruns and Heinz Otto Luthe, Wiesbaden, Harrassowitz, 2013, pp. 585-681.

WELTECKE, Dorothea, "Bemerkungen zum Kapitel über die Schule in Bar 'Ebroyos Huddoye (dem Nomokanon)", in Christsein in der islamischen Welt. Festschrift für Martin Tamcke zum 60. Geburtstag, ed. Sidney H. Griffith and Sven Grebenstein, Wiesbaden, Harrasowitz, 2015, pp. 299-311.

WELTECKE, Dorothea, “Bar 'Ebroyo on Identity. Remarks on his Historical Writing”, Hugoye: Journal of Syriac Studies 19.2 (2016), pp. 303-332.

\section{NOTES}

1. As a byproduct, Barhebraeus's stipulations become more easily accessible, as no translations of the Huddāye into a modern European language exist for the time being. Other translations and translated excerpts are listed in H. Takahashi, Barhebraeus..., pp. 228-230. See also n. 5 below.

2. H. Takahashi, Barhebraeus..., p. 67. The Syriac Orthodox church developed its own ecclesiastical hierarchy in the $6^{\text {th }}$ century CE following the Christological debates resulting from the Council of Chalcedon (451 CE). Beyond its distinct hierarchy and church organization, this community can be distinguished from other Syriac or eastern churches through its theological and liturgical tradition, despite an ongoing and rich history of exchange with other Christian denominations. For a more detailed history of the church, see S. P. Brock \& D.G.K. Taylor, The Hidden Pearl... and G. A. Kiraz, "Syrian Orthodox...". For a systematic account of the church's social history, see D. Weltecke, "60 Years after Peter Kawerau...", with the literature referenced there in f.n. 1 and 5. For an overview of Syriac Christianity in general see H. Murre-van den Berg, "Syriac Christianity...". A very useful bibliography on Syriac Christianity (stretching beyond the Syriac Orthodox church) by the Center for the Study of Christianity of the Hebrew University of Jerusalem is found at http:// www.csc.org.il/db/db.aspx?db=SB (last accessed: 2021-04-23). 
3. For an overview of the Syriac Orthodox normative tradition see A. Vööbus, The Synodicon..., and W. Selb, Die Geschichte... On the wider eastern Christian normative tradition see H. Kaufhold, "Sources...".

4. Barhebraeus has rightly been described as a polymath. He wrote works of theology (exegesis, systematic theological compendia, liturgy, ethics), philosophy (logic, philosophical compendia, psychology, astronomy), medicine, history, poetry and belles-lettres; for an overview see H. Takahashi, Barhebraeus..., pp. 57-90. In writing many of his works, he uses one principal Vorlage for the structure and much of the content, but he often incorporates a wide variety of other texts. At the same time, Barhebraeus adapts his sources, especially the Islamic ones, to his needs. For an analysis of this approach in his different writings see, among others, D. Weltecke, "Zum syrisch-orthodoxen Leben...", L. Weitz, "Al-Ghazālī...", H. Takahashi, "Reception of Islamic Theology...”, idem, “The Influence of al-Ghazālī...", F. Jäckel, "Re-Negotiating...”, and J. O. Schmitt, Barhebraeus..., forthcoming.

5. On Barhebraeus as a church leader with an eye for pastoral problems see H. Takahashi, Barhebraeus..., p.37-38, D. Weltecke, “Zum syrisch-orthodoxen Leben..." and eadem, "Bemerkungen...". There is still no critical edition of the Huddāyē; cf. n. 65 below for resulting problems. The Syriac text is published in P. Bedjan, Nomocanon..., and a Latin translation as "Ecclesiae Antiochenae Syrorum Nomocanon a Gregorio Abulpharagio Bar-hebraeo", in Scriptorum veterum nova collectio.... A pre-modern Arabic translation and Arabic glosses to a manuscript with the Syriac original of the Huddāye have not yet been studied closely; see D. Weltecke, "Bemerkungen...", pp. 303-304, and F. Jäckel, "Re-Negotiating...", p. 108, f.n. 48 and p. 126, f.n. 97. The most important earlier study is C. A. Nallino, "Il diritto musulmano...", who identified al-Ghazālì's normative writings as underlying the second part of Barhebraeus's work. Recently, D. Weltecke, “Zum syrisch-orthodoxen Leben...”, eadem, “Bemerkungen...”, L. Weitz, Syriac Christians..., pp. 284-409, idem, Between Christ and Caliph..., pp. 235-241, and F. Jäckel, "ReNegotiating...", each with a specific focus, analyzed how Barhebraeus shapes specific norms for his community by adapting his respective Christian or Islamic Vorlagen.

6. The question in what areas of jurisdiction Christians and other non-Muslims were autonomous and would use a work such as the Huddāye as reference still needs further study, especially for the post-classical period. Often, the management of Christians of their "internal affairs" is mentioned without asking what "internal affairs" actually comprise. Certainly, no general conclusions can be made. For the general topic of non-Muslim jurisdiction see N. Edelby, "The Legislative...", M. Rustow, "At the Limits...", A. M. Emon, Religious Pluralism..., M. Cohen, "Defending Jewish Judicial Autonomy...", and, still, A. Fattal, Le statut légal... , pp. 344-365.

7. The main Vorlage for Barhebraeus's Huddāyē is al-Ghazālī's (d. $1111 \mathrm{CE})$ Kitāb al-Wasiṭ. The Wasit is more extensive, but its structure and content are similar to the Kitāb al-Wağiz by the same author, so on principle both can be taken into consideration. A newly identified additional text Barhebraeus used for the Huddāyē is the Muhtașar by al-Qudūrī (d. 1036/7 CE); see F. Jäckel, "ReNegotiating...", pp.115-121. There is ample reason to take into consideration another work interrelated to the Muhtașar, namely the Hidāyah by al-Marghinānī (d. 1197 CE), see F. Jäckel, "ReNegotiating...", pp. 113 and 119, f.n. 77.

8. F. Jäckel, "Re-Negotiating...”, pp. 106-115.

9. For these normative texts, see the literature cited in n. 3 above. In this article, to compare Barhebraeus's Huddāye to his potential sources, I mostly use the collection of Syriac normative writings preserved in the manuscript Paris, Bibliothèque nationale de France, Syr. 62 (henceforth: ms. BnF Syr. 62), which is easily accessible online. For Barhebraeus's possible knowledge and use of a recension related to this manuscript, see H.G.B. Teule, "Juridical Texts..." (for Barhebraeus's Ethicon), as well as F. Jäckel, "Re-Negotiating...", p. 109, f.n. 50 and p. 117, f.n. 74 (for the Huddāyē). However, I have to correct my mistake made there, in that ms. BnF Syr. 62 is not the only manuscript to preserve the letters of Basil to Amphilochus; cf. W. Selb, Die Geschichte..., p. 112, 
f.n. 103 and H.G.B. Teule, "Juridical Texts...", p. 46. For an overview of the different manuscripts and recensions of West Syrian canon law, see the synopses in W. Selb, Die Geschichte..., pp. 100101, pp. 106-109, and pp. 120-127. One important recension of this normative collection, the so called Synodicon, was edited with an English translation by Vööbus (A. Vööbus, The Synodicon..., cf. n. 3 above) and will be referred to when applicable. However, some of the material Barhebraeus uses in the Huddāye can neither be found in ms. BnF syr. 62 nor in the Synodicon. A detailed analysis of the legal material, in all the different recensions, as well as a comparison of this material with Barhebraeus's Huddāye or Ethicon remains a desideratum in itself. Further references to sources as well as secondary literature regarding the different texts used by Barhebraeus are provided below when each text is treated.

10. For Arthur Vööbus, these alterations by Barhebraeus made the latter seem unreliable when looking for the preservation and transmission of the earlier normative tradition; A. Vööbus, Syrische Kanonessammlungen..., vol. 2, pp. 528-535.

11. F. Jäckel, “Re-Negotiating...”, pp. 109-114.

12. Following C. Strecker, "Taufrituale...", I point to P. Bourdieu, Language and Symbolic Power..., pp.117-126 ("Rites of Institution"), who carves out the social character of rites of passage. However, Bourdieu's analysis mostly pertains to distinctions within a community, e.g., the separation of male and female through (male) circumcision. Baptism (or similar rites of passages around birth) and burial, however, are common across communities while marking distinctions between them according to their respective ritual character. This topic deserves further thought. 13. Cf. C.H.F. Meyer, "Taufe und Recht... “, p. 68. This and other contributions to this issue of the journal Rechtsgeschichte - Legal History discuss legal aspects of baptism in the Medieval West and, in the case of Wolfram Brandes, in Byzantium, with significant overlap to my focus on social aspects - despite the differences of the legal and social framework in the medieval Middle East.

14. C. Strecker, "Taufrituale...", p.1413: "Wichtig ist, dass das Taufritual grundsätzlich als sozialer Konstituierungsakt der christusgläubigen Gemeinschaften fungierte, indem es generell Zugehörigkeit und Nichtzugehörigkeit markierte und performativ herstellte."

15. See A. Louth, “'Fiunt non nascuntur Christiani'...”, pp. 109-114.

16. The time gap between birth and baptism cannot be overlooked but must be seen in relation to a high rate of infant mortality: the liminal character of life before birth extends to the first days or weeks of life. For example, Barhebraeus cites Aristotle when stating that newborns are not named until some days after birth as they are still in danger; see his treatment of procreation in the philosophical summa Hệwat hekmtā in the manuscript Damascus, Syrian Orthodox Patriarchate, ms. 239 (=6/2), fol. 122v; cf. Aristotle, Historia Animalium IX.12 (588a1-12 Bekker).

17. Accordingly, in the Huddāye, Barhebraeus tacitly adds to a canon by the council of NeoCaesaraea (ca. $315 \mathrm{CE}$ ) that the child of a pregnant catechumen is baptized after his or her birth, see F. Jäckel, “Re-Negotiating...”, pp. 108-109.

18. For the problems in identifying these texts, see W. Selb, Die Geschichte..., p. 92. For an overview of these texts in the Eastern churches see H. Kaufhold, "Sources...", pp. 241-244, with further references. In what follows, I additionally refer to the edition by de Lagarde (P. de Lagarde, Reliquiae...) where appropriate.

19. Huddāyēe, ed. Bedjan 1898, p. 20, 1.4-5. Cf. ms. BnF syr. 62, fol.117r, 1. 5-9 and ed. de Lagarde 1856, Syriac, p. 52, 1. 10-13; cf. also The Synodicon..., trans. Vööbus 1975-1976, vol. 1, p. 78, 1. 6-9.

20. Huddāyēe, ed. Bedjan 1898, p. 20, 1.6-7. Cf. ms. BnF syr. 62, fol.118r, 1.2-3 and ed. de Lagarde 1856, Syriac, p. 54, 1.7-9; cf. also The Synodicon..., trans. Vööbus 1975-1976, vol.1., 79, 1.16-18, where "three times" is missing.

21. For example, he explains "baptizing three times" as "immersion three times", most likely to distinguish it from three distinct baptism rituals.

22. In research on baptism, this is known as the "necessity of baptism". Here, too, theological aspects of baptism are under scrutiny, i.e., the soteriological necessity of baptism; for 
Barhebraeus see, e.g., W. de Vries, Sakramententheologie..., pp.116-119. Certainly, there exists a link between communal, or rather ecclesiological aspects (the church as community, the believer as its member) and soteriological ones (the church as salvific community, of which one becomes a member through baptism). Still, such research topics differ from how baptism works to construct community.

23. Huddāyē, ed. Bedjan 1898, p. 24, 1.1-3. Cf. ms. BnF syr. 62, fol. 183v, 1. 15-17 and fol. 184r, 1. 1013, which are two rulings from the Responsa canonica (see CPG 2520) by Timothy; cf. also The Synodicon..., trans. Vööbus 1975-1976, vol. 1, p. 138, 1. 28-32 and p. 139, 1. 18-23. Barhebraeus here combines two separate rulings, thereby stipulating the exception "if death is near" in the case of the menstruating woman as well, which is absent in his source. The reference to "Timātēos the patriarch" by Barhebraeus pointing to Timothy I of Alexandria should not be confused with other references to "Ṭimātēos Qātoliqā d-nesțoryāno" pointing to the East-Syrian Timothy I (d. $823 \mathrm{CE}$ ); for these latter references see now J. O. Schmitt, “Some Remarks...", pp. 160-161 with f.n. 33.

24. Cf. Huddāye, ed. Bedjan 1898, p. 24, 1.16-17, where Barhebraeus decrees (using a ruling by John the Patriarch, d. 873 CE; cf. The Synodicon..., trans. Vööbus 1975-1976, vol. 2, p. 47, 1. 3-5) that godparents need to be of the same gender as their godchild; cf. also Huddāye, ed. Bedjan 1898, p. 25, 1.14-15. Another interesting case is the role of the deaconess, who takes care of the acts during baptism involving the body of a woman; Huddāye, ed. Bedjan 1898, p. 26, 1. 4-10 (using a ruling by the Didascalia). Another huddāyā is added decreeing that "in our days" a piece of cloth between the priest and a woman to be baptized is necessary, thus further limiting the bodily contact between them. Deaconesses are not mentioned, as this female office was likely not extant in Barhebraeus's times. Accordingly, the stipulation upholds separation of gender under new circumstances.

25. Huddāyēe, ed. Bedjan 1898, p. 24, 1.3-7. For the Vorlage, cf. a stipulation by Jacob of Edessa in his answers to Addai as translated by F. Nau, "Les résolutions...", p. 51 (n³1). N 31-34 of this collection seem to be missing in ms. BnF syr. 62; cf. also The Synodicon..., trans. Vööbus 1975-1976, vol. 1, p. 243, 1.24-28. In the Synodicon, however, the problem is not that there is no body of water, but that there is no church. Cf. also the detailed discussion of this ruling by C. Kayser, Die Canones Jacob's..., pp. 120-123.

26. Huddāyē, ed. Bedjan 1898, p. 24, 1.7-8. This addition was pointed out already by F. Nau, "Les résolutions...", p.52, f.n.1. Nau suggests the amendment "angel 'of death"' ; cf., however, C. Kayser, Die Canones...", pp. 122-123, who suggests that it means the guardian angel of the child.

27. Cf. F. Jäckel, "Re-Negotiating...", pp.106-115, where I analyze the case of burial for a miscarried child along these lines. See also the literature cited in n. 5 above. For the addition Barhebraeus makes, see also C. Kayser, Die Canones..., pp. 122-123.

28. Huddāyēe, ed. Bedjan 1898, p. 23, 1.9-11. Cf. ms. BnF syr. 62, fol. 229v, 1.27-29; cf. also The Synodicon..., trans. Vööbus 1975-1976, vol.1, p.157, 1.12-13. In both normative collections just referenced, some rulings attributed to Severus are actually included in the Chapters from the Orient, for which see W. Selb, Die Geschichte..., pp. 113-114, with further references. Barhebraeus's attribution of these rulings to Severus could help to identify the recension of the different normative collections that were at Barhebraeus's disposal, but this is beyond the scope of this article; cf. Hubert Kaufhold's contribution "Severos von Antiochien als Jurist und Kanonist" at the conference "Severus of Antioch and His Search for the Unity of the Church: 1500 Years Commemoration of his Exile in 518 AD" held at Salzburg in 2018, the publication of which is in preparation. On Severus of Antioch, see S. P. Brock, “Severus of Antioch...". For his reception see L. van Rompay, "Severus, Patriarch...", especially p.10. Severus's normative stipulations are scattered throughout his letters, i.e., there is no one legal treatise or work of his. For his standing as an important normative authority, cf. the many excerpts of his writings in normative collections treated and listed in W. Selb, Die Geschichte..., p. 115 and pp. 122-123. 
29. Huddāyē, ed. Bedjan 1898, p. 23, 1.11-12. For the Vorlage, which is also found in the Chapters of the Orient, though attributed by Barhebraeus to Severus, cf. ms. BnF syr. 62, fol. 230r, 1. 11-12; cf. also The Synodicon..., trans. Vööbus 1975-1976, vol. 1, p. 157, 1.28-32. For the importance of the myron oil in Syriac baptism see K. Pinggéra, "Myron".

30. Here and in what follows, the term "heretic" and similar attributions are adopted from the source. The same is true regarding the term "orthodox" etc., if not used in proper names. Throughout my paper, I use these or similar terms in a non-normative way to describe the position taken by Barhebraeus (or his source texts).

31. Huddāye, ed. Bedjan 1898, p. 20, 1.8-9. Barhebraeus here abridges a ruling included in a Collection of Apostolic Canons, for which see W. Selb, Die Geschichte..., pp. 95-96; cf. ms. BnF syr. 62, fol. 116v, 1. 24 - fol. 117r, 1.5 and ed. Lagarde 1856, Syriac p. 52, 1.5-10; cf. also The Synodicon..., trans. Vööbus 1975-1976, vol. 1., p. 78, 1. 1-5.

32. For a systematic summary, see W. Selb, Die Geschichte..., pp. 295-296.

33. Huddāye, ed. Bedjan 1898, p. 20, 1.10-14. Cf. ms. BnF syr. 62, fol.147v, 1.1-10; cf. also The Synodicon..., trans. Vööbus 1975-1976, vol. 1, p. 120, 1.9-16. On the Council of Laodicea see F.J.E. Boddens Hosang, Establishing Boundaries..., pp. 91-106.

34. D. Weltecke, “Zum syrisch-orthodoxen Leben...”, pp. 606-607.

35. Huddāyēe, ed. Bedjan 1898, p. 20,1.19 - p. 21, 1.12. Barhebraeus credits the ruling to a certain Euqāris (?) of Constantinople. In the Latin translation, this is suggested to be Proclus of Constantinople; see Huddāyē, trans. Assemanus/Mai 1838, p. 12. The ruling corresponds to canon 7 of the Council of Constantinople (381 CE) in the later Greek recension. However, it is not included in the Latin or Syriac translation of these canons; cf. H. Ohme, "Sources...", p. 50, and W. Selb, Die Geschichte..., p. 99. Rather, canon 7 goes back to a Letter from Constantinople to Martyrios, Bishop of Antioch on the conversion of heretics; cf. ms. BnF syr. 62 , fol. $247 \mathrm{v}, 1.32-$ fol. $248 \mathrm{v}, 1.1$ and the translation by F. Nau, "Littérature...", pp. 119-120. There, the letter is ascribed to "Euqarisidā, his own, who was dwelling there", i.e., in Constantinople or in Antioch? Nau interprets this as "his apocrisiarius". Specific variations like these need further research to identify Barhebraeus's exact sources. I wish to thank Hubert Kaufhold for detailed information on these sources.

36. Huddāyēe, ed. Bedjan 1898, p. 21, 1. 18 - p. 22, 1. 8. This is an excerpt from a letter by Severus, cf. ms. BnF syr. 62, fol. 249r, 1. 15 - fol. 250r, 1. 13; cf. also The Synodicon..., trans. Vööbus 1975-1976, vol. 1 , p. $175,1.20$ - p. 177, 1. 15. In comparison, however, Barhebraeus also includes the decree by the "Fathers of Ephesus" (i.e., the Council of Ephesus in 431 CE?) stating that the ones who turn away from the heresy of Theodore and Nestorius are neither baptized nor anointed. This points in the direction of the full letter by Severus; cf. the translation in Brooks 1904, pp. 299300. Details will need further research. Once more, I wish to thank Hubert Kaufhold for detailed information on the sources.

37. Huddāye, ed. Bedjan 1898. p. 22, 1.8-9. Cf. ms. BnF syr. 62, fol.232r, 1.5-7; cf. also The Synodicon..., trans. Vööbus 1975-1976, vol.1, p.161, 1.10-17. Again, this ruling is attributed to Severus, but included in the Chapters from the Orient, see n. 28 above.

38. A similar distinction between different kinds of outsiders was explicitly drawn already by Severus, however not treating pagans or non-Christians; cf. the references in n. 36 above. Cf. also the sources from the Byzantine context to this effect as discussed by W. Brandes, "Taufe und soziale/politische Inklusion...", with further references.

39. See Huddāye, ed. Bedjan 1898, p. 21, 1. 12-17. This is taken from Cyprian's letter to Quintus ( ${ }^{\circ}$ 60 , see CPL 50), the Syriac translation of which would need further study on the whole. As this letter is included in ms. BnF syr. 62, the link of Barhebraeus's source to this recension is further corroborated (cf. f. n. 9 above). Barhebraeus abridges his Vorlage to include only the basic idea. One alteration by Barhebraeus is noteworthy: Cyprian relates an ongoing dispute inside the church during his time. Accordingly, in his letter the "certain ones" to have a wrong opinion are identified as his fellow bishops. (On Cyprian and the issue of valid baptism in his time, see E. E. 
Popkes, "Die Tauftheologie Cyprians...") Barhebraeus omits this attribution, possibly because it would lead to misconceptions outside of the original context. In consequence, Barhebraeus would see East-Syrians and Chalcedonians as members of one Catholic Church, as they do not need to be re-baptized. However, one should not assume an all too strict consistency in the Huddāye. For Barhebraeus's dogmatic ecumenism, see P. Conlin, "Eradicating the Root of Hatred...", with further references; cf. also D. Weltecke, "Bar 'Ebroyo...".

40. See the references in $n .36$ above.

41. An alternative explanation would be that Barhebraeus wants to maintain normative flexibility by presenting different opinions. Another example of abrogation, which I will take up in the second section of the article, is Barhebraeus's qualification of burial through heretical priests, see page 17 below; also, cf. the role of the deaconess mentioned in n. 24 above. Concerning abrogation or a variety of readings, in Severus's original writing one finds the interesting notion that "regarding the benefit and unity of the church [...] we must not be prejudiced and be held captive by previous opinions"; The Synodicon..., trans. Vööbus 1975-1976, vol. 1, p. 176, 1. 30-32 - hence the changes of the church's stance. Barhebraeus thus finds the idea of normative flexibility already in the tradition.

42. Huddāye, ed. Bedjan 1898, p. 22, 1.14-28. Here, ms. BnF syr. 62 , fol. $273 \mathrm{r}-284 \mathrm{v}$ with the respective canons by Jacob is corrupted towards the end. Cf. the text in The Synodicon..., ed. Vööbus 1975-1976, vol. 1, p. 253, 1. 4-27 and trans. Vööbus 1975-1976, vol. 1, p. 231, 1. 21 - p. 232, 1. 8 .

43. For the Vorlage, see n. 25 above. On Jacob of Edessa, see A. G. Salvesen, "Ya'qub of Edessa...". For Jacob's normative work, see the contributions by H.G.B. Teule \& K. D. Jenner in the volume by B. ter Haar Romeny (ed.), Jacob of Edessa....

44. Huddāyēe, ed. Bedjan 1898, p. 22, 1. 8-14. Cf. ms. BnF syr. 62, fol. 231v, 1. 33 - fol. 232r, 1. 5; cf. also The Synodicon..., trans. Vööbus 1975-1976, vol. 1, p. 161, 1.3-9. Again, this ruling is attributed to Severus, but included in the Chapters from the Orient; see n. 28 above.

45. See, e.g., M. P. Penn, Envisioning Islam..., and J. J. van Ginkel et al. (eds.), Redefining Christian Identity....

46. Huddāye, ed. Bedjan 1898, p. 22, 1.20-22. Since the original canons of George are not preserved, their use by Barhebraeus cannot be compared against the original text. On George of the Arabs, see J. Tannous, "Between Christology...". For a collection of George's writings, including the citations extracted from Barhebraeus's Huddāyē, see V. Ryssel, Georgs des Araberbischofs Gedichte....

47. W. Selb, Die Geschichte..., p. 296 opines that similar rulings rule out re-baptism.

48. For Late Antiquity, see É. Rebillard, The Care of the Dead..., pp. 13-36. For Islamic times, see L. Halevi, Muhammad's Grave..., and J. Tannous, The Making..., p. 102, p. 105, p. 237, pp. 410-11 and pp. 445-448. In addition, there is the interesting issue of the burial of a non-Muslim woman who is pregnant with a child by a Muslim father, which is treated by Ibn al-Qayyim (d. $1350 \mathrm{CE}$ ); see A. Bosanquet, Minding their Place..., pp. 323; cf. also pp. 186-189.

49. Beyond Late Antiquity and apart from studies on liturgical formulas etc., research on Eastern Christian funeral practice seems little developed. For the Copts, see Archbishop Basilius, "Burial Rites and Practices" in Coptic Encyclopedia, ed. A. S. Atiya (https://ccdl.claremont.edu/digital/ collection/cce/id/389/rec/30, accessed 2021-04-23); for the Maronites, see R. J. Mouawad, "Recherche...". For an account of supposed Syriac Orthodox burial practice from Mosul in 1290 CE, see F. J. Dölger, “Totenritual...”. For Byzantium, see D. Abrahamse, “Rituals ...”.

50. Huddāyē, ed. Bedjan 1898, p. 70, 1.16 - p. 71, 1.14. The phrases in passive voice are rendered in the third person plural masculine in Syriac, without however explicitly naming an agent. The Syriac forms of the third person singular masculine have been translated with the singular they, where gender was not determined by context (as in the case of the male clergy). Also, cf. the 
German translations in C. Kayser, Die Canones..., pp.153-154 and R. Kohlhaas, Jakobitische Sakramententheologie..., pp. 78-79.

51. For this Islamic text as well as al-Ġazālī's Kitāb al-Wasịt as Vorlagen for Barhebraeus's Huddāye see F. Jäckel, "Re-Negotiating...", and the literature cited in n. 5 above. For their respective treatment of funeral rites cf. al-Ġazālī, Kitāb al-Wasịt, ed. A. M. Ibrāhīm, Cairo, vol. 2, pp. 359-396, and al-Qudūrī, al-Muhtașar, ed. and trans. T. M. Kiānī, pp. 74-79. Other aspects of the rite, especially pertaining to the order of prayers, are taken by Barhebraeus from a ruling by PseudoDionysius the Areopagite (fl. ca. $500 \mathrm{CE}$ ), which is also the first ruling in chapter 6 of the Huddāye; see ed. Bedjan 1898, p.68, 1.9-18. However, this ruling does not include the actual actions performed on the deceased. For the sixth part of Barhebraeus's dogmatic work Mnārat qudše ("The Candelabre of Sanctities"), which treats the sacraments, his use of Pseudo-Dionysius's On the Ecclesiastical Hierarchy has been noted as well; see R. Kohlhaas, Jakobitische Sakramententheologie..., p. 3. Also, see Mnārat quďsē, trans. Kohlhaas 1959, ibidem, pp. 42-47, where some parts of the rites are to be found. In general, the relation of the Christian and Islamic rites is likely due to a shared and much older tradition, which cannot be assessed within this article.

52. Cf. al-Qudūrī, al-Muhtașar, ed. and trans. Kiānī 2015, p. 74. Differently from this, al-Ġazālī’s Kitāb al-Wasit stipulates to whisper the creed into the dying person's ear (which corresponds to a similar Islamic practice at birth); cf. ed. Ibrāhīm 1997, vol. 2, p. 362. For Islamic funeral rites in general, see L. Halevi, "Funerary practices".

53. Cf. Mark Cohen, Under Crescent and Cross. The Jews in the Middle Ages, Princeton and Oxford, Princeton University Press, 2008, pp. 62-63 ("Symbols of Separation and Humiliation").

54. On the Ecclesiastical Hierarchy 7.3.7, trans. J. Parker, The Works..., vol. 2, p. 158.

55. It seems, as if Barhebraeus leaves open what exactly is liturgically practiced in the dead person's house. Interestingly, a distinction between male and female is absent and only found regarding who is supposed to wash a dead person's body in an earlier ruling; cf. Huddāyē, ed. Bedjan 1898, p.70, 1.15. The spatial distinction regarding the burial services for clergy and laypeople appears also in stipulations which Barhebraeus takes up from Jacob of Edessa; cf. what is referenced in $n .58$ below.

56. See F. Jäckel, “Re-Negotiating...”, pp. 106-115.

57. This idea might be taken by Barhebraeus from al-Marghīnānī's Hidāya, which extends and comments al-Qudūrī's Muhtașar. Here, similar ideas are put forward regarding the burial of captive children, right after the stipulations for the miscarried child; see F. Jäckel, "ReNegotiating", p. 113.

58. Huddāyēe, ed. Bedjan 1898, p. 69, 1. 16. Cf. the Šu'āle ("questions") by John the Stylite (Johannān Esțunārā) to Jacob. They are missing in ms. BnF syr. 62, but cf. The Synodicon..., trans. Vööbus 1975-1976, vol. 1, p. 220, 1. 16 - p. 222, 1. 15.

59. The bad smell as the actual cause for the practice is only made explicit by Jacob, not in Barhebraeus's summary.

60. Huddāyēe, ed. Bedjan 1898, p. 70, 1.13-16. Usually, Barhebraeus's attribution of a ruling to the Persians implies it to be part of the East-Syrian Synodicon orientale, for which see L. van Rompay, "Synodicon Orientale". In this case, the ruling is seemingly not extant in the manuscripts of the Synodicon orientale. However, a parallel ruling can be found in two later legal works from the EastSyrian tradition, the Arabic Fiqh an-Nașrāniyya by Ibn al-Tayyib (d. $1043 \mathrm{CE}$ ), see trans. W. Hoenerbach \& O. Spies, Fiqh an-Nașrāniya..., vol. 2, p.111, 1.23-34, as well as in the Kunnāšā d-qānonē sunhādiqāyē by 'Abdisho' bar Brikha (d. $1318 \mathrm{CE}$ ), in Scriptorum veterum nova collectio..., p. 255.a29-b16; cf. C. Kayser, Die Canones..., p. 154.

61. Another interesting aspect is the apparent chastity behind the omission of the washing of the body of the clergy and the stipulation that the undergarments are not removed when they are prepared for burial (cf. the translated passage on page 13 above). 
62. This is dealt with by Barhebraeus in three consecutive rulings; Huddāye, ed. Bedjan 1898, p. 73, 1. 4-7, p. 73, 1.7-11 and p. 73, 1.12-14. The Vorlage of the first two rulings are the canons of the Synod under the Syriac-Orthodox Patriarch John III (in 846 CE) and under Patriarch Ignatius II (in 878 CE), respectively; cf. The Synodicon..., trans. Vööbus 1975-1976, vol. 2, p. 47, 1. 9-19 and p. 59, 1.13-21. The third ruling is attributed to the Persians, cf. n. 60 above. Here, the precedent of the ruling stems from the Synod of the East-Syrian Catholicos Mar Ezechiel (in $576 \mathrm{CE}$ ); see ed. J.-B. Chabot, Synodicon Orientale ..., p. 117, 1. 9-14, translation on p. 376 (Paragraph IV).

63. In Islam, similar regulations of funeral practices involving constructions of community and gender can be found, see Halevi, Muhammad's Grave..., pp.138-142, with many references to Christian practices, and N. M. El Cheikh, Women, Islam..., pp. 38-58. For Christian antiquity, see now S.L.M. Mogen, Mourning..., pp. 248-296.

64. Huddāyēe, ed. Bedjan 1898, p. 69, 1. 7-13. The Vorlage are the Šu'ālē ("questions") which John of Tella was asked by a priest named Sargīs; cf. ms. BnF syr. 62, fol. 270r, 1. 4-28, trans. Nau 1906, pp. 14-15 (n $\left.{ }^{\circ} 27-29\right)$ and The Synodicon..., trans. Vööbus 1975-1976, vol.1, p. 201, 1.29 - p. 202, 1. 11. For John of Tella, see V. L. Menze, "Yuhanon of Tella..."

65. Huddāye ed. ed Bedjan 1898, p. 69, 1.13-15. This abrogative huddāyā is missing in the oldest extant witness of the Huddāyē, ms. Pampaduka, Library of the Konat family, ms. 33, for which see H. Kaufhold, Syrische Handschriften..., pp. 18-19 and pp. 28-37. I am very grateful to Hubert Kaufhold for pointing this out to me. Regarding these differences in the text, the huddāy $\bar{a}$ might be an addition by later recipients. In this case, my argument of reading such rulings with respect to construction of community can be applied not only to Barhebraeus as the author but can be extended to the users of the texts. Alternetivaly, the huddāya could have been left out on purpose in this early ms. Problems like these can only be solved by a critical edition of the Huddāye.

66. Huddāyēe, ed. Bedjan 1898, p. 73, 1.19 - p. 74, 1.2. The precedent for the respective ruling is not extant in ms. BnF syr. 62. It belongs to the collection of Further Questions of Addai to Jacob, extant, e.g., in the manuscript Mardin, Church of the Forty Martyrs, ms. 310 (https://www.vhmml.org/ readingRoom/view/503660, accessed 2021-04-23), fol.213r-215v. For this collection, see R. G. Hoyland, Seeing Islam..., p. 604. The folio numbers for the Further Questions in ms. Mardin 310 given by Hoyland as well as by Vööbus, "Syrische Kanonessammlungen...”, vol. 2, p. 452, f.n. 52 seem to be off. I thank Jan van Ginkel for pointing me to the Further Questions of Addai and the respective manuscript.

67. On the Syriac commoners, see J. Tannous, The Making of...

68. In general, Barhebraeus gives an excerpt of the entire discourse. The two anecdotes at the end - about the Maccabees praying for their forcefully converted brethren and Pelagius praying for an unbaptized catechumen girl who has died - are found in Jacob. The reference to Dionysius and John might be found in another recension of the Further Questions, however.

69. Huddāye, ed. Bedjan 1898, p. 73, 1.3-5. Since the ruling by Jacob immediately before is not extant, it is not clear if this is already part of Jacob's dictum. In another place, Jacob in fact refers explicitly to Pseudo-Dionysius as an authority; cf. page 15 above. The reference to John likely points to the response by John of Tella already treated above; see page 17.

70. Huddāye ed. Bedjan 1898, p. 70, 1.7-9. That outsiders participate in one's own processions is explicitly mentioned as well. 


\section{ABSTRACTS}

This paper analyzes the legal text called the Huddāye composed in Syriac by the Syriac Orthodox polymath Barhebraeus (d. 1286) in regard to stipulations about baptism and burial. Stressing the importance of baptism and burial for the community as rites of passage, it examines what demarcation lines are drawn by Barhebraeus regarding outsiders. In this respect, two types of outsiders must be considered: Christians of other denominations (e.g., East Syrians) and Muslims. The earlier normative texts, which Barhebraeus refers to contain similar communal demarcation lines, but are altered, expanded and redacted by Barhebraeus, thus bringing them into a coherent whole.

Este artigo analisa o texto legal designado Huddāyē, composto em Siríaco pelo polimato ortodoxo siríaco Barhebraeus (d. 1286), relativo a estipulações sobre baptismo e enterramento. Sublinhando a importância do baptismo e do enterro para a comunidade dos sírios ortodoxos como ritos de passagem, este artigo examina que linhas de demarcação são traçadas por Barhebraeus em relação aos outros não pertencentes àquela. A este respeito, dois tipos de forasteiros devem ser considerados: cristãos de outras denominações (por exemplo, sírios orientais) e muçulmanos. Os textos normativos anteriores a que Barhebraeus se refere contêm linhas de demarcação comunitárias semelhantes, mas são alterados, ampliados e redactados por Barhebraeus, que os transforma num todo coerente.

\section{INDEX}

Keywords: baptism, funeral rites, Barhebraeus, Syriac Christianity, canon law

Palavras-chave: batismo, ritos de funeral, Barhebraeus, cristianismo siríaco, direito canónico

\section{AUTHOR}

\section{FLORIAN JÄCKEL}

Universität Hamburg

florian.jaeckel@uni-hamburg.de 